Check for updates

London

Cite this as: BMJ 2020;371:m4092 http://dx.doi.org/10.1136/bmj.m4092 Published: 21 October 2020

\section{Covid-19: Second wave death rate is doubling fortnightly but is lower and slower than in March}

\author{
Shaun Griffin
}

England and Wales registered 9954 deaths in the week ending 9 October 2020, $1.5 \%$ above the five year average, provisional data from the Office for National Statistics (ONS) have shown. ${ }^{1}$ Of these deaths, $4.4 \%$ (438) mentioned covid-19, up from 3.2\% (117) the previous week.

Sheila Bird, former programme leader at the MRC Biostatistics Unit at the University of Cambridge and a member of the Royal Statistical Society's covid-19 taskforce, said, "There's no let-up yet in the rate of increase in England's covid-19 deaths."

Commenting on the trend, she said, "In the first three weeks of March 2020, deaths increased by a factor of 10, week on week. The weekly rate of increase then moderated to below doubling in the first two weeks of April."

Bird added that covid-19 deaths were now more than doubling fortnightly (a rate of 2.2). However, the "rate of increase ... is currently lower and slower than in March 2020, when it was initially 10-fold," she said. "The bad news is that the rate has not started to abate ... we need to moderate down the rate of increase over the coming weeks, and the sooner the better, by changing our close contact patterns in England, as Scotland's central belt did from 13 October for two weeks, and Wales did [on 19 October].”

Reduced contact patterns would need to be sustained, she concluded, “for months, not just weeks, to see us through the winter. Serial 'circuit breakers' can help us rein in exuberances.”

\section{Regional differences}

During the week ending 9 October, deaths involving covid-19 increased in seven of the nine English regions from the previous week. Of the 401 deaths in England that mentioned covid, the highest number (153) occurred in the north west. Over the same period the number of covid deaths in Wales increased from 25 to 37.

The ONS reported that $16.3 \%$ of all deaths registered in the week to 9 October mentioned "influenza and pneumonia," covid-19, or both, up from $14.8 \%$ the previous week. While deaths in hospitals and care homes remained below the five year average in the week ending 9 October-374 fewer in hospitals and 175 fewer in care homes-those in private homes remained above the five year average (705 more).

Back in May the ONS reported that deaths from covid-19 accounted for only half of the excess deaths taking place in private homes. ${ }^{2}$ The Nuffield Trust reported this week that deaths registered from the week ending 13 March through to 9 October were $40 \%$ higher than the five year average in private homes and care homes and were $4 \%$ higher in hospitals. ${ }^{3}$
Commenting on the figures, Sarah Scobie, deputy director of research at the Nuffield Trust, said, "We have now seen an additional 29 ooo deaths at home since March. ONS analysis suggests many of these deaths would usually have taken place in care or hospital settings.

"Supporting people to die at home with their loved ones around them has been an important policy objective for many years. But we need to delve deeper to understand the role that patient choice or reluctance to access health services play in this stark increase, and whether patients and families are getting the help and support they need at home."

Office for National Statistics. Deaths registered weekly in England and Wales, provisional: week ending 9 October 2020. 20 Oct 2020. https://www.ons.gov.uk/peoplepopulationandcommunity/birthsdeathsandmarriages/deaths/bulletins/deathsregisteredweeklyinenglandandwalesprovisional/weekending9october2020.

2 Griffin S. Covid-19: "Huge rise" in deaths at home is not fully explained by virus, say experts. BMJ 2020;369:m2115 doi: 10.1136/bmj.m2115 pmid: 32461232

3 Nuffield Trust. Measuring mortality during covid-19: a Q\&A. 20 Oct 2020. https://www.nuffieldtrust.org.uk/news-item/measuring-mortality-duringcovid-19-a-q-a.

This article is made freely available for use in accordance with BMJ's website terms and conditions for the duration of the covid-19 pandemic or until otherwise determined by BMJ. You may use, download and print the article for any lawful, non-commercial purpose (including text and data mining) provided that all copyright notices and trade marks are retained. 